\title{
Enhancement Of The Designer Performance In Office Interior Design
}

\author{
Tuğba Karaaslan \\ İTÜ Istanbul Technical University \\ Interior Architecture Department, IMIAD, Turkey \\ Dr. Deniz Ayşe Yazıcıoğlu \\ Istanbul Technical University \\ Interior Architecture Department, Turkey
}

\begin{abstract}
It is also a reality in the literature that the developing and changing conditions have become inevitable for being considered in the area of interior space design and application and being directed towards restructuring works in this regard. In this approach, one of the key concepts is "performance-based design". It is also being tried to develop models intended for determination of factors affecting the performance of a specific actor, within a certain period, among the works related to the performance. One of the most important actors for interior space design is the designer. In Kleeman's opinion, designer's success primarily depends on his/her capability to fulfill accurately and completely the evaluations intended for recognizing the user at the preliminary stage. Because, the success of interior space design, is measured through to what extent it meets the user's desires and needs. In this context, the purpose of the study has been decided as reviewing the documents used during determination of the user's desires and needs at the preliminary stage and recommending necessary revisions in order to acquire complete, accurate data. The scope of the study has been limited to only office interior space design projects for the purpose of reaching detailed results. In line with this scope and objective defined, literature and practical application resources have been investigated as the methodology at the first stage in order to determine the documents utilized towards recognition of the user at office design. Afterwards, the entire documents obtained have been examined by comparing in a systematic manner and deficiencies of these documents have been set forth. And at the last stage, some suggestions have been made for elimination of these deficiencies.
\end{abstract}

Keywords: Performance based design, office interior design, clientquestionnaire.

\section{INTRODUCTION}

It is also a reality in the literature that the developing and changing conditions have become inevitable for being considered in the area of interior space design and application and being directed towards restructuring works in this regard. In this approach, one of the key concepts is "performance-based design", and in this direction it is inevitable to be reconsidered of the entire design process from an integrated point of view $[1 ; 2]$.

"Performance" is a measurable phenomenon. The realization of achievement of any purpose according to which criteria, with a performance at which level, is as important as reaching the goal. How to increase the performance has become one of the basic subjects discussed in recent years in both literature, and its practice side.

Among the studies associated with the performance, it is also being tried to develop models for determination of factors affecting the performance of a specific actor, at a certain process [1; 2]. 
One of the most important actors for interior space design and implementation is the designer. In Kleeman's [3] opinion, designer's success primarily depends on his/her capability to fulfill in a healthy manner the evaluations intended for recognizing the user at the preliminary stage. Because, the success of interior space design, is measured through to what extent it meets the user's needs and adequate time should be allocated for the interviews conducted to determine these needs. Ching [4] strongly emphasizes the necessity of taking into consideration the users and action requirements in order to understand the function of the interior space in a best and most accurate way and to meet the necessitites associated with them. Meanwhile, Arcan and Evic [4] state that the combination of single actions resulting from the requirements of the user who is the element required to be considered most in this process forms the action areas, and the action areas form the usage areas by coming together, after expressing that the user is the criterion of everything in the design process. In this context, they stress that interior space design is also carried out via arrangement of appropriate circulation areas of action areas and necessary equipping elements. In other words, the interior space is configured for its user. Stephenson and Stephenson [6] state in a manner supporting all these thoughts that the designer might have valuable ideas at the beginning point; however these ideas are of no importance in case of being incompatible with the needs and wishes of the user.

Due to all these reasons, wishes and needs are identified in consultation with the user at the outset of the design process. There're various documents that will assist the designer to make correct identifications at this stage. Completeness and accuracy of the data acquired from these documents will substantially enhance the performance of the designer in project-planning process.

\section{PURPOSE AND METHODOLOGY}

The purpose of the study has been decided to examine the documents used for identification of users' wishes and needs at the preliminary stage of interior architecture project and to make necessary suggestions in order to obtain complete, accurate data through these documents. And the scope of the study has been limited to only office interior space design projects for the purpose of reaching detailed results. The reason for preference of office spaces is the time spent at workplaces constituting a very significant part of lives of many people [7; 8]. In the first stage, the documents used intended for determination of users' wishes and needsin office interior space design will be investigated as the methodology in accordance with this scope and aim defined. Afterwards, the entire documents obtained will be examined by comparing in a systematic manner and deficiencies of these documents have been set forth. And in the final stage of the study, some suggestions will be submitted for elimination of these deficiencies.

\section{EXAMINATION OF THE DOCUMENTS USED FOR THE PURPOSE OF DETERMINATION OF USERS' WISHES AND NEEDS IN OFFICE INTERIOR SPACE DESIGN}

In the first stage, literature and practical application resources have been investigated in order to discover the documents used for identification of users' wishes and need in office interior space design. As a result of these studies conducted, a total of 288 questions have been acquired from 21 different resources $[9 ; 10 ; 11 ; 12 ; 13 ; 14 ; 15 ; 16 ; 17 ; 18 ; 19 ; 20 ; 21 ; 22 ; 23$; $24 ; 25 ; 26 ; 27 ; 28 ; 29]$. Later, these aforementioned 288 questions have been examined in a comparative manner and they have been reduced to a total of 92 questions by eliminating the ones showing similarity. Meanwhile, in the last stage these 92 questions have been divided into two basic groups depending on the nature of answers to be received. These are:

Questions intended for identification of user opinions regarding existing office interior space design (Table 1), Questions intended for identification of user wishes and needs related to office interior space design to be done soon (Table 2). 
Table 2. Questions intended for identification of user wishes and needs related to office interior space design to be donesoon

Questions How easily does your office internal arrangement meet the changes that will occur in needs?

Are you pleased with the environmental factors of your office?

How satis fied are you with the opportunities of your office?

How satis fied are you with technological facilities of your office?

How pleased are you with the noise in the areas linked to the office?

Does your flooring make noise in a manner that will affect your concentration during daily circulation in the office?

Have the material and color selection of the flooring used in your office been used effectively in separation of certain departments, private/public areas and circulation paths?

Are areas available in your office for working in a concentrated manner?

How satisfied are you with design and aesthetic criteria of your office?

Has suspended ceiling application been made in your office?

Do you have adequate privacy in your personal work space?

Can you customize your work space?

Can you re-arrange your office furniture when necessary?

What is the distance between the walls or furniture and your workspace?

Are there suitable equipments and areas in sufficient number needed for the teamwork in your office?

What is the number and sizes of meeting rooms in your office?

Is the layout of the meeting spaces in your office appropriate?

Do the meeting spaces have necessary tools and technology in your office?

Is your workspace far from kitchen/coffee area in your office?

Is your workspace far from main circulation area in your office?

Do you hesitate to talk in common areas where copiers/printers are present in your office?

Is your workspace far from meeting rooms in your office? Is there sufficient area in your personal workspace for meetings/talks in your office?

Are the layout of kitchen/coffee spaces appropriate in your office?

Which furniture do you share with your other workmates?

If you use copier/printer, where is it located?

Has your office got any automation system?

Has your office got a lighting control or shading system?

Are the doors and windows enough?

Is your company publicized through visual elements at reception side?

Do visual elements and accessories in your office reflect the style of your company?

What do you think, have appropriate furniture and ambience been designed in the present arrangement for participants to communicate with each other?

Has any design been made intended for gaining interoffice space?

References

[9] [10] [11] [12] [13] [14] [15] [16] [17] [18] [19] [20] [21] [22] [23] [24] [25] [26] [27] [28] [29] $\mathrm{X}$

$\begin{array}{llllll} & x & & \\ x & x & & x \\ x & x & x & x \\ x & x & x & x \\ x & x & x & x\end{array}$

Is there a sufficient number of toilets for the use of staff in your office? Are they separately for women and men?

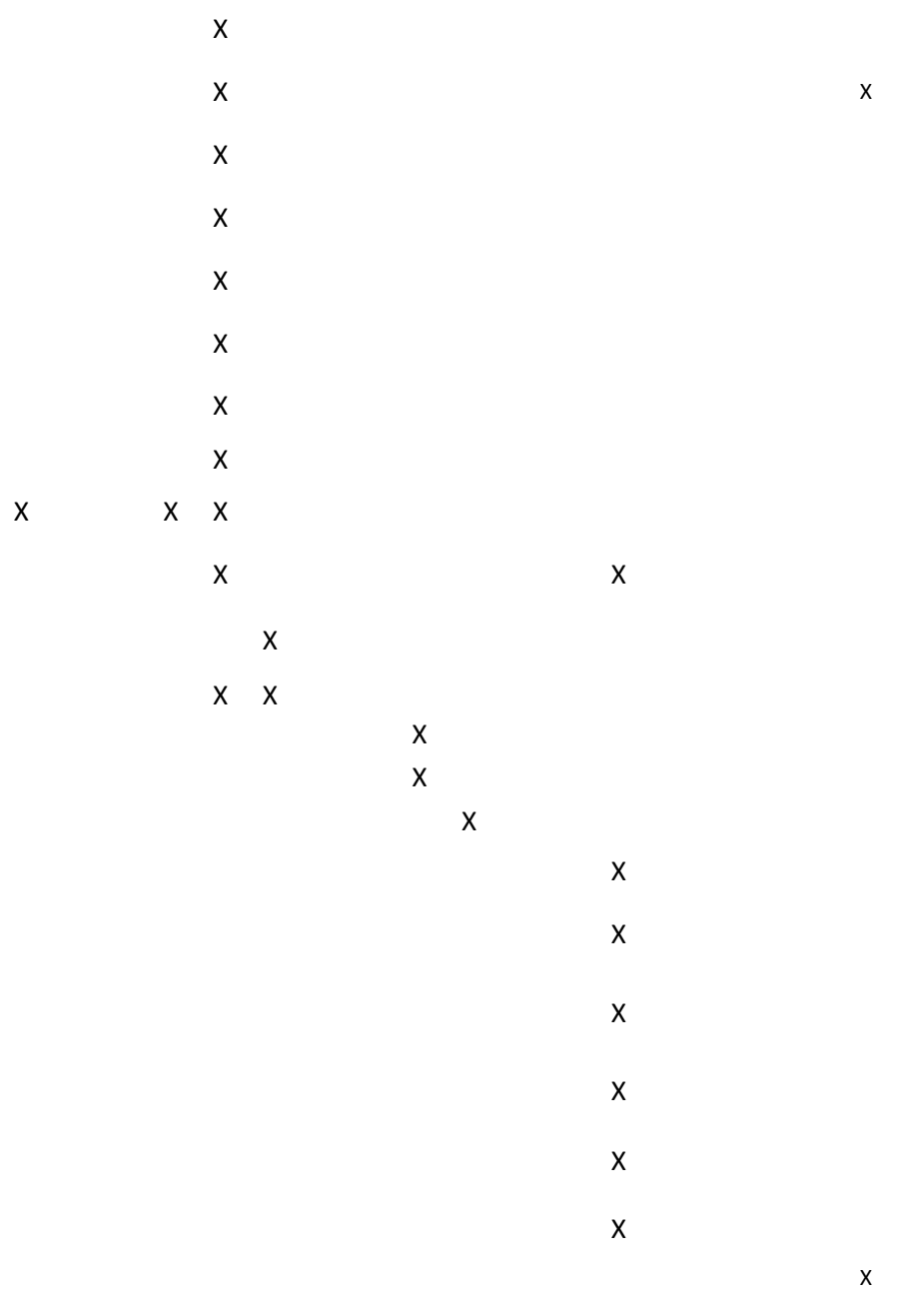
room?

What are the sizes of closed and open office 
Table 1. Questions intended for identification of user opinions regarding existing office interior space design

\begin{tabular}{|c|c|c|c|c|c|c|c|c|c|c|c|c|c|c|c|c|c|c|}
\hline \multirow[b]{2}{*}{ Questions } & \multicolumn{18}{|c|}{ References } \\
\hline & [9] [ & [10] & [11] [12 & 2] [13] & ] [14 & ] [15] & [17] & [18] & [19] & $\frac{20]}{[20]}$ & [21] & [22] & [23] & [25] & [26] & [27] & [28] & [29] \\
\hline What are the main business activities of your company? & & $\mathrm{X}$ & & $\mathrm{X}$ & & & & & & & & & & & & & $\mathrm{X}$ & \\
\hline What is the size/volume of your company? & & $\mathrm{x}$ & & & & & & & & & & $\mathrm{X}$ & & & & & & \\
\hline What is the level of recognition of your company? & & $\mathrm{x}$ & & & & & & & & & & & & & & & & \\
\hline Who are your typical customers? & & $x$ & & & & & & & & & & & & & & & & \\
\hline Who are your rivals in the market? & & $\mathrm{X}$ & & & & & & & & & & & & & & & & \\
\hline What is your budget? & & & & & & & & & $\mathrm{x}$ & & $\mathrm{X}$ & & & & $\mathrm{X}$ & $\mathrm{X}$ & & \\
\hline What is the expected start date of the project? & & & & & & & & & & & & $\mathrm{X}$ & & & & & & \\
\hline What is the time allocated for the design and building process? & & & & & & & & & & $\mathrm{X}$ & & & $\mathrm{X}$ & $\mathrm{X}$ & & $\mathrm{x}$ & & \\
\hline What is the monthly rent or monetary value of the project area? & & & & & & & & & & & & $\mathrm{x}$ & & & & & & \\
\hline What is the monetary value of neighboring areas? & & & & & & & & & & & & $\mathrm{x}$ & & & & & & \\
\hline What is the age of the building? & & & & & & & & & & & & $\mathrm{x}$ & & & & & & \\
\hline Who is the primary decision maker during the project period? & & & & & & & & & & & & & $\mathrm{X}$ & & & $\mathrm{X}$ & & \\
\hline What is the scope of the project? & & & & & & & & & & & & & $\mathrm{x}$ & & $\mathrm{x}$ & & & \\
\hline What is the total area? & & & & & & & & & & & & $\mathrm{x}$ & & & & & & \\
\hline Which qualifications are needed in the design team? & & & & & & & & & & & & & $\mathrm{x}$ & $\mathrm{x}$ & & $\mathrm{X}$ & & \\
\hline What are your preferences about design styles and color? & & & & & & & & & $\mathrm{x}$ & & $\mathrm{x}$ & $\mathrm{x}$ & & $\mathrm{x}$ & $\mathrm{x}$ & $\mathrm{x}$ & & $\mathrm{x}$ \\
\hline What are your preferences in terms of office furniture? & & & & & & & $\mathrm{X}$ & & & & & & & & & & & $\mathrm{x}$ \\
\hline Do you want structural change? & & & & & & & & & & & $\mathrm{X}$ & & & & $\mathrm{X}$ & & & \\
\hline Is there any rule for making structural change? & & & & & & & & & & & $\mathrm{x}$ & & & & & & & \\
\hline What kind of spaces do you need in terms of functionality/size? & & $\mathrm{x}$ & $\mathrm{x}$ & $\mathrm{x}$ & & & & & $\mathrm{x}$ & & $\mathrm{x}$ & & $\mathrm{X}$ & $\mathrm{X}$ & $\mathrm{X}$ & & $\mathrm{X}$ & \\
\hline How a workspace do you need? & & & $\mathrm{x}$ & $x$ & $\mathrm{x}$ & & $\mathrm{X}$ & $\mathrm{x}$ & $x$ & & & $\mathrm{X}$ & & & & & & $\mathrm{X}$ \\
\hline What is the circulation density in the office? & & & & & & & & & $\mathrm{x}$ & & & & & & & & & \\
\hline Do you have any personal preference related to the $\mathrm{d}$ & & & $x$ & & & & & & & & & & & & & & & \\
\hline
\end{tabular}

Do you want to increase transparency in the office?

How effective is the office aesthetics and design on the personnel satisfaction?

Are there people who're working from home in your office?

At what interval and in what way do you use your office?

Which environmental condition is the most important factor in performing your work?

Which office dynamics is the most important factor in

performing your work?

Which office opportunities have the most important effect on performing your job?

Which technological factors have the most important effect on performing your job?

Which one has the most important effect on performing your job?

If you're using your workspace for meetings and interviews,

what is the maximum number of people in these activities?

To what extent your meetings necessitate visual and acoustic confidentiality?

How often do you make meetings in the rooms outside the

workspace?

Which area do you prefer for a joint work in the office?

What are the preferences of the institution for informal meeting areas?

What are the preferences of the institution for formal meeting rooms?

What visual/audial confidentiality level should be in the office?

What are the distracting factors in your workspace?

Which sharing reduces your productivity?

What are the first three choices of the institution to improve the collaborative work environment in the office?

What are the first three choices of the institution to enhance the learning environment in the office?

Do you make teamwork with other employees? How long was your last teamwork?

What should be the distance between you and other people worked together?

Which sizes and properties of storage areas do you need?

What are the office supplies that you use most?

How many of the files, which you have produced or got from somewhere else, do you keep?

How long do your works remain in your workspace?

How do the works to be done reach your desk?

Do you share files with another employee?

How often do you use reference material?

Are there large graphical materials exhibited in your workspace? Do you use pinboard, flipchart etc. for working?

What kind of artificial lighting is needed in the general space and private workspaces?

$x$

$\mathrm{X}$

$\mathrm{X} \quad \mathrm{X}$

$\mathrm{x}$

$x$

$x$

$\mathrm{X}$

$x$

$\mathrm{X} \quad \mathrm{X}$ $\begin{array}{lll} & x & x \\ x & x & x \\ & x\end{array}$ 
When the questions for finding out the users' views regarding the existing office interior space design in Table 1 are evaluated, it has been seen that they're 37 in total; however their numerical distributions differed in each document. For example; evaluations are made for determination of user

views related to existing office interior space design on the basis of 11 questions by Hua [16], 6 questions by Hameed and Amjas [12], and only 1 question by Gensler [9]. In other words, it has been discovered that there's an embodiment intended for acquisition of information at different levels and nature from these documents used for same purpose.

When the questions intended for identification of user wishes and needs related to office interior space design to be done soon in Table 2 are evaluated, it has been seen that these are 55 in total, however their numerical distribution differed in each document just like in Table 1. For example, evaluations are made for determination of user views related to office interior space design to be donesoon on the basis of 6 questions by Spencer [10], 3 questions by Lee and Brand [14] and only 1 question by Wilkinson, et.al. [18]. In other words, it has been discovered that there's an embodiment intended for acquisition of information at different levels and nature from these documents used for same purpose also in Table 2 just like in Table 1.

Additionally, when the data in Table 1 and Table 2 are analyzed, it has been seen that no problem has been identified for learning whether there're users (handicapped, etc.) requiring specific design or ergonomic features of the users. However, project planning of all components belonging to the space in compliance with the user's competencies and physical feature is the most fundamental necessity in terms of success of the design.

When the whole data acquired under the study is examined, it is seen that the questions were 92 in total towards determining the users' views on existing and futureoffice interior space design (Table 1, Table 2). However, it has been ascertained that even Fmlink [17], who has the most evaluation questions, used only 22 of them. In other words, 70 different questions that will help to define the user's wishes and needs are neglected even in the resource that allows for gathering the most comprehensive data.

When 92 questions listed in Table 1 and Table 2 are analyzed, most of them have been observed to be in the nature of hampering to get clear and correct answers. For example; the answer to be given for the color by the user to the question of "What are your preferences about design styles and color? is probably going to be gray, dark blue, caramel etc. However, the possibility of sameness is very low for the definitions such as light gray or dark blue meant by the user and the color tones corresponding these names in the mind of the designer. A mistake to be done here, may cause the occurrence of undesirable consequences in terms of user pleasure. In other words, there's no embodiment to provide language unity between the user and the designer in existing documents.

When the questions in Table 1 and Table 2 are examined, it has been observed that there're not any problems towards cultural implications. However, the workplace has its social, cultural and psychological implications; furniture designers need to be aware of these consequences. For example, Europeans generally prefer products to be long-lasting and appreciate a sense of history, whereas countries such as Japan are more interested in the disposable and replaceable [30]. Also, in France culture dictates one should not work with one's back towards someone entering through the door $[31 ; 32]$. 
When the questions in Table 1 and Table 2 are analyzed, it is seen that there's not a clear problem intended for identifying the work flow process of the company that will use the office. However, Morrow et. Al. [33] emphasizes that one of the most important criteria in office interior space design is the identification of the firm's workflow process at the preliminary stage. Elsbach and Bechky [34] and Hua et. al. [35] state that imperfect knowledge on this subject will create trouble in respect of the compatibility of the business with physical working areas in new office design, and so this will considerably affect the performance of employees.

It is impossible to identify user wishes and needs at sufficient levels and correctly through present documents due to all these incompleteness determined. Therefore, some suggestions will be made for the elimination of this incompleteness at the next stage of the study.

\section{RECOMMENDATIONS FOR IDENTIFICATION OF USER WISHES AND NEEDS AT A SUFFICENT LEVEL AND CORRECTLY IN OFFICE INTERIOR SPACE DESIGN}

It is recommended to use the entire 92 different questions listed in Table 1 and Table 2, when composing new documents that will enable the identification of user wishes and needs at a sufficient level and correctly in office interior space design.

It is recommended to define questions towards learning the users' ergonomic features or whether there is users (handicapped, etc) requiring specific design in the documents to be created newly. The question of "What are the anthropometric dimensions of the users" which is going to be one of the most important among these questions, should be described in an attribute that can be answered by considering the action groups and the action to be carried out in the space. In other words, documents must contain which anthropometric dimensions are required to be taken for which actions.

It is recommended to structure the questions in new documents in a nature to ensure getting clear and correct answers. As in the color example given above, it must be allowed to choose among a color chart instead of saying the tone and name of the color by the user when answering the question of "What are your preferences about design styles and color?

It is recommended to create questions towards identification of cultural characteristics of firm employees in new documents. The criteria such as age, gender, social status must be taken into consideration when determining the cultural characteristics. Because the wishes and needs of individuals having same culture differ depending on the criteria like age, gender.

It is recommended to compose questions intended for identification of workflow process of the company which are not available in existing documents but significantly affecting the success of office interior space design. The questions should be created precisely towards identification of the system/systems used in document management by the company in order to carry out faultlessly the workflow process, the participants taken part in realization of each action, the action groups and the action of every step of the workflow process when identifying these questions.

Each of these recommendations made within scope of the study intended for improvement of the documents, are in the nature of separate scientific studies. The conclusions to be acquired from these scientific studies will allow for correctly and precisely structuring the documents that will be created soon.

\section{RESULTS}

It would be possible to determine user wishes and needs regarding office interior space designs in a more correct way through the use of documents to be composed in line with the 
recommendations made within scope of the study. And so this will significantly enhance the performance of the designer.

\section{References}

[1] Yazıcıoğlu, D.A. (2014). An Analytical Approach on Improvement of Kitchen Design Performance In Terms of Psycho-Social User Requirements In Turkey, Advances in Social Sciences Research Journal, Vol. 6, No. 1, 2014, pp. 179-186.

[2] Arslan, S. and Kanoğlu, A. (2010).Başarım Tabanlı Yapım: Anahtar Kavramlar, Olanaklar, Bariyerler ve Bir Model, 1. Proje ve Yapım Yönetimi Kongresi, 29 Eylül - 1 Ekim 20100DTÜ Kültür ve Kongre Merkezi, Ankara.

[3] Kleeman, W.B. (1982).The Need For Ergonomics Expertise in Office Design, Applied Ergonomics, Vol.13, No.2, pp.125-127

[4] Ching, F.D.K. (2004). İç Mekan Tasarımı-Resimli, Yapı Yayın, İstanbul.

[5] Arcan, E.F. and Evci, F. (1992). Mimari Tasarıma Yaklaşım 1-Bina Bilgisi Çalışmaları, İki k Yayınevi, İstanbul.

[6] Stephenson, H. and Stephenson, L. (1960). Interior Design, Studio Books, London.

[7] Danielsson, C.B. (2008). Office Experiences, Royal Institute of Technology, Elsevier Ltd., Stockholm, Sweden, pp.605-628.

[8] Mazumdar, S. (1992). Sir, Please Do Not Take Away My Cubicle: The Phenomenon of Environmental Deprivation, Environment and Behavior, Vol. 24, No.6, pp.691-722.

[9] Gensler (2005 ). Architect of Ideas:These Four Walls: The Real British Office, <http://www.gensler.com/uploads/document/60/file/7fcf25b05a2c0839c44655d1645c40ec.pdf.com>, viewed: 17 October 2014.

[10]Spencer, L., (2009). 42 Questions Every Freelancer Should Ask Their Clients, <http://freelancefolder.com/42questions-every-freelancer-should-ask-their-clients/>, viewed: 22 October 2014.

[11]Girard, L. (2013). Growth Strategies, 10 Questions to Ask When Designing Your Office, Entrepreneur, <http://www.entrepreneur.com/article/226839>, viewed: 22 October 2014.

[12]Hameed, A. and Amjad, A. (2009). Impact of Office Design on Employees' Productivity: A Case study of Banking, Journal of Public Affairs, Administration and Management, Vol.3, No.1, pp.10-13.

[13] Oatway, C. (2004). Office Environment \& Design Questionnaire, <http://www.my3q.com/home2/44/eastlake/91470.phtml?estination=/home2/44/eastlake/91470.phtml>, viewed: 23 October 2014.

[14]Lee, S.A. and Brand, J.L. (2005). Effects Of Control Over Office Workspace on Perceptions Of The Work Environment And Work Outcomes, Journal of Environmental Psychology, Vol. 25, Vol. 3, pp.331-332.

[15]Veitch, J.A., Charles, K.E., Farley, K.M.J. and Newsham, G.R. (2007). A Model of Satisfaction With Open-Plan Office Conditions: COPE Field Findings, Journal of Environmental Psychology, Vol. 27, No.3, pp.8.

[16]Hua, Y.(2010). A Model of Workplace Environment Satisfaction, Collaboration Experience, And Perceived Collaboration Effectiveness: A Survey Instrument, International Journal of Facility Management, Vol. 1, No. 2, pp.7-8.

[17]FM Link-Building Owners and Managers Institute's Facilities Planning and Project Management (2002). Facilities Check List, Practical, step-by-step guides for the busy FM - Work Space Requirements Questionnaire, FM Link, $<$ http://www.fmlink.com/article.cgi?type=How\%20To\&title=Work\%20Space $\% 20$ Requirements $\% 20$ Questionnaire \%20\&pub=BOMI\%20International\&id=40884\&mode=source $>$, viewed: 2 November 2014.

[18]Wilkinson, S.J., Reed, R.G.and Jailani, J. (2011). User Satisfaction in Sustainable Office Buildings: A Preliminary Study, 17th PRRES Pacific Rim Real Estate Society Conference, 2011, 16-19 January, Gold Coast, Avusturalya. 
[19]Interior Design Pro. (2014). 10 Questions Your Interior Designer May Ask You, <http://www.interiordesignpro.org/blog/interior-designer-may-ask-you>, viewed: 28 August 2014.

[20]Home Tech Design. (2014). Questionnaire: Commercial - Home Tech Design, <http://hometechdesign.com/en/contact-us/client-questionnaire-commercial>, viewed: 28 August 2014.

[21]Sample Questionnaire, (2014). Sample Commercial Interior Design Questionnaire, <http://www.samplequestionnaire.com/commercial-interior-design-questionnaire.html>, viewed: 28 August 2014.

[22]The Designer Finder. (2014). Interior Designer Client Profile Questionnaire, $<$ http://thedesignerfinder.com/interior design client profile.htm>, viewed: 28 August 2014.

[23]Pulp Design Studios. (2014). New Client Questionnaire, < http://pulpdesignstudios.com/client-questionnaire/>, viewed: 28 August 2014.

[24] Serene Interiors. (2014). How to Design Office, <http://www.sereneinteriors.com/how-to-design-youroffice.html>, viewed: 28 August 2014.

[25]Bruce, E.(2014). Residental and Small Commercial Project Handbook, <http://www.edwinbruce.com/Images/ResidentialProjectHandbook.pdf>, viewed: 28 August 2014.

[26]Harrington Collage of Design. (2012). 3 Questions to Ask Your Interior Design Clients, <http://www.harrington.edu/Student-Life/Blog/July-2012/3-Questions-To-Ask-Your-Interior-Design-Clients >, viewed: 28 August 2014.

[27]Fairley, T. (2014). 10 Questions to Ask Your Design Clients, <http://www.wsidesignermarketplace.com/content/designer/Design Blog/2012/02/10 questions to ask.html>, viewed: 28 August 2014.

[28]Interiors. (2014). Office Decoration - Guide to Colours, Flooring, Window Treatments, Furniture and Accessories, <http:/www.gdlinteriors.com/articles/office-design-and-refurbishment.html>, viewed: 28 August 2014.

[29]Wang, Y. (2009). Evaluating Office Users' Requirements and Occupiers' Preferences in Changing Business Environment, Master Thesis, Helsinki University of Technology, Faculty of Engineering and Architecture, Department of Surveying, Espoo, Finlandiya.

[30]Dythan, M (2001) New is Now by Carolien van Tilburg, Frame, Vol.23, pp.53.

[31]Pe'legrin-Genel, E (1996) The Office Flammarion, Italy.

[32]Anjum, N., Paul, J. and Ashcroft, R. (2005). The Changing Environment of Offices-A Challenge For Furniture Design, Design Studies, Vol.26, No.1, pp.73-95.

[33]Morrow, P.C., McElroy, J.C. and Scheibe, K.P. (2012). Influencing Organizational Commitment Through Office Redesign, Journal of Vocational Behavior, Vol.81, pp. 99-111.

[34]Elsbach, K. D. and Bechky, B. A. (2007). It's More Than A Desk: Working Smarter Through Leveraged Office Design, California Management Review, Vol.49, No.2, pp.80-101.

[35]Hua, Y., Loftness, V., Heerwagen, J. H. And Powell, K. M. (2011). Relationship Between Workplace Spatial Settings And Occupant-Perceived Support For Collaboration, Environment and Behavior, Vol.43, pp.807-826. 